\title{
Death of a salesman?
}

\section{David M. Ritson}

Teller's War: The Top-Secret Story Behind the Star Wars Deception. By William L. Broad. Simon and Schuster: 1992. Pp. 380. \$25.

IN 1985 William Broad, science correspondent for the New York Times, wrote The Star Warriors, describing his sevenday visit to the Lawrence Livermore National Laboratory to research a story on the fission bomb-driven $\mathrm{X}$-ray laser project. He was a guest at the home of Lowell Wood, a division head, and was sold on the project mainly by Wood's vision and flair for public relations. Now, in what in many senses is a followon book, Broad presents an obsessively researched and documented chronicle of the pathological oversell of this component of 'Star Wars'. Who better than a reformed alcoholic to preach the dangers of alcohol?

It is hard now to recall how controversial the Strategic Defense Inititiative (SDI) was only a few years ago and how, under the cover of almost complete government classification, it was so difficult to distinguish fact from fiction in the scientific claims made for the various weapons systems. Centre-stage in the controversy for several years were Edward Teller and the X-ray laser, followed by "Brilliant Pebbles", in which thousands of small independent interceptors would be stationed in space. Teller's reply to criticism at the time was invariably "if you only knew what I know". Now, with Broad's research, we can indeed all know both what was known and what was claimed. And not surprisingly, the claims went outrageously beyond the facts.

What made all of these revelations possible were the grievance hearings brought before the University of California at Berkeley in 1987 by Roy Woodruff. As an associate director for nuclear weapons at Livermore, Woodruff had been directly responsible for supervising the X-ray laser programme. He resigned from the post in October 1985, alleging that the project had been grossly misrepresented. During the hearings, he complained of reprisals and penalization for his stance. The hearings were leaked, providing a great deal of information about the project. The demise of SDI in its 1980s manifestation has also made many of the main protagonists ready and willing to discuss the project both on and off the record. Broad has exploited the situation essentially to declassify the $\mathrm{X}$ ray laser component. The resulting book is fascinating and addictive.

Its weakness lies in its simplistic depictions and plot. Broad characterizes Teller as the principal architect of SDI and portrays the X-ray laser as though it were the main component of the programme. In fact, the X-ray laser programme cost about 2 billion dollars out of a total expenditure on SDI in the 1980s of around 25 billion dollars. There are three main players in the book. Teller: "Largely divorced from dispassionate peers, Teller drew on the vast reservoir of his own ideas, dreams, passions and frustrations. Foremost among his frustra-

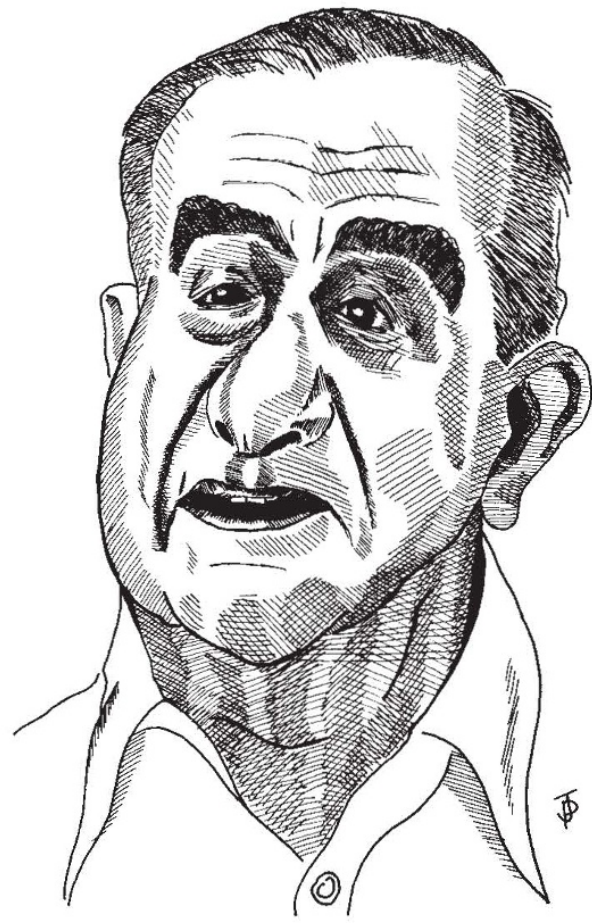

tions was the military might of the Soviet Union." Wood: "a youthful colleague who provided no moderation at all but seemed to goad Teller onwards .... Wood was an extension of Teller, a protégé, an intellectual devotee who pledged allegiance to the Tellerian creed, and struggled to carry it forward." And, pitted against the two, is Woodruff: "Young and idealistic, headstrong and unfamiliar with the corridors of scientific moderation of which he was only partly aware. He was ready to bring the visionary Teller down to earth." A subplot running through the book is the representation of Teller: "Most fundamentally the trouble in Teller's life can be traced to a breakdown in relations with colleagues.... Teller needed peers to give integrity to the wanderings of his extraordinarily vivid imagination. Bereft of interaction with colleagues, he was an undisciplined dreamer." It is, of course, true that even after all the other protagonists in the 1954 US Atomic Energy Commission hearings concerning Oppenheimer's opposition to the development of the $\mathrm{H}$-bomb are forgiven or forgotten, the physicists of that era have never forgiven Teller. But that generation has now all but exited from the stage, and the principal actors today hardly remember those times. Probably a far more important problem is the immense ego that has always driven Teller, which must make it hard for him to brook contradiction.

Broad does an excellent job of portraying the travails of a 'whistle blower'. Woodruff was plagued before finally leaving Livermore by multiple investigations, a cut in salary and isolation from his colleagues. What is missing, however, is an account of the wider arena of the Star Wars programme, and of the forces that drove it and, for that matter, continue to do so as it changes (at an ever increasing cost) to become a shield against attack from Saddam Hussein and his ilk. It is comforting to believe that Star Wars was simply an aberration in Teller and Reagan's judgements, with one autocratic brilliant old man selling another less-brilliant old man on a joint dream. This is indeed the picture that Broad paints. The reality, when it finally comes to be written, is likely to be more interesting and more disquieting. Many members of the Reagan administration were tough, intelligent and pragmatic individuals, motivated by their discontent with military parity and a desire to re-establish US superiority in that respect. Under the circumstances, it is hard to determine to what extent Teller used the system and to what extent it used him.

In his epilogue, Broad raises but fails to answer many of the more interesting questions, such as how a responsible director at Livermore could have tolerated such flagrant misrepresentations by its public-relations people; why the system of checks and balances did not function better; and where the University of California's management and supervision were through all of this. My own cynical view is that the scientific community can deal very well with scams such as cold fusion where only millions of dollars are at risk, but that it collapses over big projects where billions or hundreds of billions of dollars are in question. For its wealth of new facts and careful documentation of the science behind SDI, Broad's book deserves to be widely read.

David M. Ritson is emeritus professor of physics, Stanford Linear Accelerator Center, Stanford University, Stanford, California 94305-4060, USA. 